\title{
Historical perspectives of The American Association for Thoracic Surgery: Henry T. Bahnson (1920-2003)
}

\author{
Thomas A. D'Amico, MD, and The American Association for Thoracic Surgery Centennial Committee
}

Henry Theodore Bahnson (Figure 1), 57th president of The American Association for Thoracic Surgery (AATS), was born in Winston-Salem, North Carolina, on November 15, 1920. The third of 4 sons, he was reared in a family that valued hard work, integrity, and education-values that he would emulate throughout his career. ${ }^{1}$ He received his undergraduate education at Davidson College, where he excelled academically and athletically. He was president of his class, was president of his fraternity, and graduated Phi Beta Kappa and Omicron Delta Kappa (BS, 1941). He completed his medical degree cum laude from the Harvard Medical School in 1944, where he was the valedictorian. As a second-year medical student, he performed coagulation research in the Thorndike Laboratory at Boston City Hospital, and as a fourth-year student he conducted research with Dr Lewis Dexter at the Peter Bent Brigham Hospital. He was 1 of only 6 third-year students to be elected to the Alpha Omega Alpha Honor Society, and 1 of 3 to be awarded a John Harvard Fellowship. ${ }^{1}$

Bahnson was accepted into the training program in surgery at Johns Hopkins by Dr Alfred Blalock (30th AATS president). Just before moving to Baltimore, Bahnson received permission to marry from Blalock, who generally preferred his residents to be single. Bahnson and his wife Louise were to raise 2 daughters and 3 sons, 1 of whom was named after Blalock. After surgical internship at the Johns Hopkins Hospital Bahnson served 1 year in the US Navy Reserves in the Philippines. He then returned to Hopkins to complete his surgical residency from 1946 through 1951, during which he also spent a year in a National Research Council Fellowship at the University of Rochester, where he helped use an animal model of coarctation of the aorta to elucidate the renal humoral influence on blood pressure control. ${ }^{3}$ Other residents at Johns Hopkins at that time included Drs Sabiston, Spencer, Morrow, Hanlon, Longmire, Scott, Cooley, and Muller, an unusually talented and productive group that went on to dominate American surgery for almost a generation. ${ }^{4}$

Early in Bahnson's training, Blalock's operation for tetralogy of Fallot had achieved worldwide attention. In

From the Department of Thoracic Surgery, Duke University Medical, Durham, NC. Disclosures: Author has nothing to disclose with regard to commercial support.

Received for publication Oct 1, 2012; accepted for publication Oct 15, 2012; available ahead of print Nov 9, 2012.

Address for reprints: Thomas A. D'Amico, MD, Duke University Medical Center, Box 3496, Duke South, White Zone, Room 3589, Durham, NC 27710 (E-mail: damic001@mc.duke.edu).

J Thorac Cardiovasc Surg 2013;145:326-7

$0022-5223 / \$ 36.00$

Copyright (C) 2013 by The American Association for Thoracic Surgery

http://dx.doi.org/10.1016/j.jtcvs.2012.10.024
1947, Bahnson accompanied Blalock on a visit to London, Stockholm, and Paris to lecture on the Blalock-Taussig operation and to perform surgery. While visiting the Hospital Broussais in Paris, Blalock performed 7 cases with Bahnson at his side. ${ }^{5}$ After being away for 6 weeks, Blalock was tiring and asked Bahnson to do a case one morning while toured the royal gardens. This time it was not a tetralogy repair, as they had performed to that point, but repair of a patent ductus arteriosus. Without hesitation, Bahnson, as a resident, went on to perform the first successful closure of a patent ductus in France. ${ }^{1}$

After his residency, Bahnson remained on the faculty at Johns Hopkins from 1952 through 1963. Within a very short time, he was recognized as a leader in treatment of abdominal aortic aneurysms, ${ }^{6}$ adult cardiac surgery, ${ }^{7}$ and congenital heart surgery. ${ }^{8}$ He pioneered aortic valve replacement with single-leaflet replacement. ${ }^{9}$ In addition, he brought closedchest compression cardiopulmonary resuscitation from the experimental laboratories at Johns Hopkins into clinical use. ${ }^{10}$

Blalock delegated the development of cardiac and vascular surgery at Hopkins to Bahnson and Dr Frank Spencer (63rd AATS president). Only 18 months after completing their training, Bahnson and Spencer were invited to Sidney, Australia, to supervise cardiac surgery at the Royal Prince Alfred Hospital. They shipped a Lillehei heart-lung machine to Sidney and tested it first in the canine laboratory. During testing, all the animals died. Bahnson was not slowed by this apparent failure, however, which he attributed to the canine species. He and Spencer proceeded to perform cardiac surgery on 30 patients in the span of 4 weeks without a single death. ${ }^{2}$

In 1961, Bahnson was promoted to the rank of professor of surgery. The next year, he spent 3 months at the University of Vienna assisting Professor Fritz Helmer in the development of a modern cardiovascular surgery service. ${ }^{1}$ On his return from Vienna in 1963, he was recruited and appointed as the George V. Foster Professor of Surgery and chair of the Department of Surgery at the University of Pittsburgh, a position he would hold for 24 years, transforming the department "from a position of indifference to empowering significance." $2 \mathrm{He}$ was the longest-serving chair in the school's 116-year history and was the first to hold the Foster Chair in Surgery. ${ }^{1}$

In addition to being a world-class surgeon and surgical investigator, Bahnson was a devoted teacher. His trainees usually had their first operative experience with their department chair after 6 to 8 exhausting hours of a cardiac procedure, when the sleep-deprived intern would be called on to close the arterial connection to the heart-lung machine with rudimentary instruments and sutures. As the fledgling 


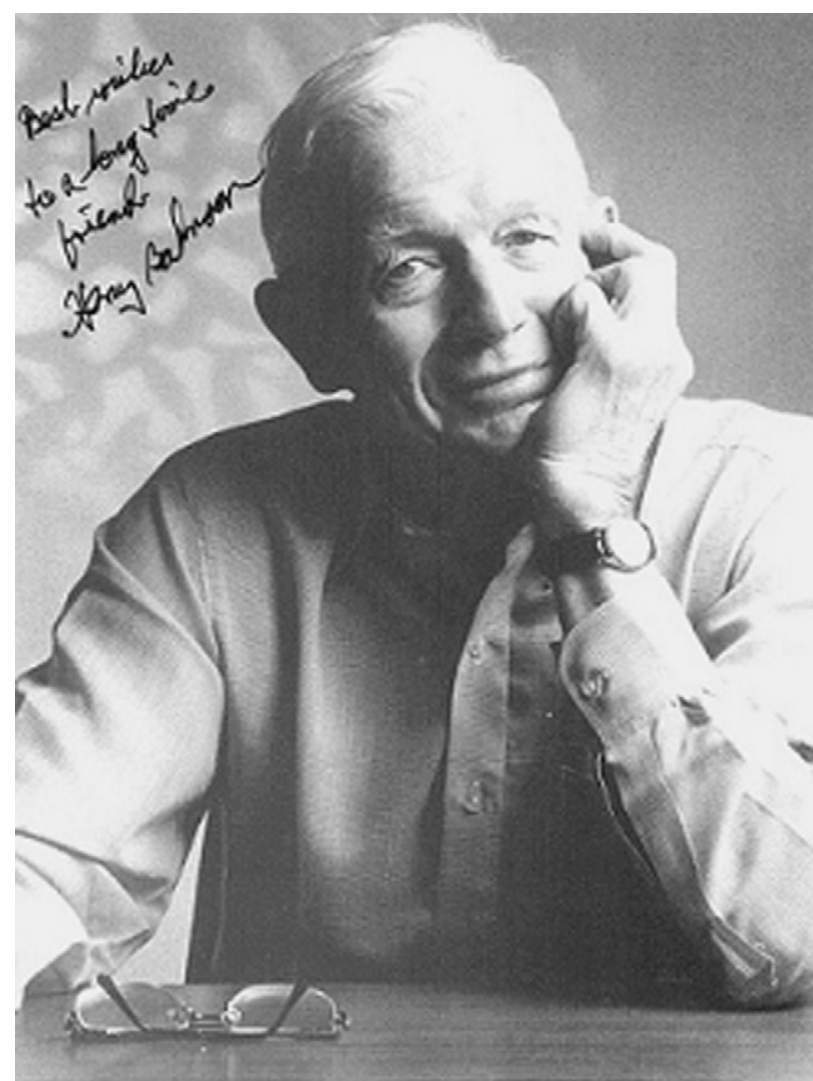

FIGURE 1. Henry T. Bahnson, MD.

surgeon struggled to tie a square knot, Bahnson would pressurize the moment with the cautionary advice, "Don't break it." Still, residents appreciated and understood his patience and dedication to teaching and were committed to his leadership and to the program.

Unlike many of his contemporaries, Bahnson also had a variety of interests outside surgery. He was an avid athlete: a successful college football player, climber, skier, sailor, cyclist, and equestrian. At Davidson, he was a linemansmall for the position even then, but tenacious. His fondness for high-altitude mountain climbing was infamous. To train for his often month-long Himalayan absences, he would run the 50 flights of stairs in Pitt's Cathedral of Learning with a rock-loaded rucksack on his back. As if this were not enough to keep his mind and body occupied outside the hospital, he was a botanist, a beekeeper, and an outstanding black-and-white photographer. Notably, most who knew him learned firsthand of his interest in the harmonica, an interest said to have been fostered by having a voice that could not "carry a tune in a bucket." ${ }^{2,4}$ Bahnson's interest in the harmonica was the subject of a front-page article in The Wall Street Journal, ${ }^{11}$ a video, ${ }^{12}$ and his final peerreviewed manuscript in 1998, which was published in a music journal, the Journal of the Acoustical Society of America. ${ }^{13}$
In April 1977, Bahnson presided over the 57th Annual Meeting of the AATS in Toronto. He was the senior author of an important paper at this meeting regarding subvalvular aortic stenosis, ${ }^{14}$ and he also delivered his presidential address, "Our Obligation to Developing Nations." ${ }^{15}$ Bahnson spoke eloquently and presciently about the imperative of the global nature of medicine, a concept that continues to be relevant today. Specifically, he discussed the value of American thoracic surgeons in the teaching and training of foreign medical graduates, as evidenced by the Evarts Graham Travelling Fellowship. He also cited the contribution of American surgeons traveling to teach and operate in foreign lands.

Henry Bahnson died on January 10, 2003, at the age of 82 years of complications of a massive stroke that he had had 2 weeks previously. ${ }^{16}$ Despite his age, he remained academically active to the end, giving his last overseas lecture only 6 weeks before he died in Moscow, where he was recognized by the Bakoulev Scientific Center for his contributions to the development of cardiovascular surgery in Russia. ${ }^{4}$ At his memorial service at Heinz Chapel at the University of Pittsburgh, it was remembered that Bahnson had an unusual balance of intellectual curiosity, emotional control, and physical strength that permitted him to excel. ${ }^{4}$ It was also remembered that his family values of hard work, integrity, and education framed a career that has been matched by very few in the history of cardiothoracic surgery.

\section{References}

1. Sabiston DC Jr. Henry T. Bahnson. Clin Cardiol. 1994;17:49-50.

2. Griffith BP. Henry T. Bahnson, MD (1920-2003): Himalayas of the mindchallenges and expectations. J Thorac Cardiovasc Surg. 2004;128:1-3.

3. Scott HW Jr, Bahnson HT. Evidence for a renal factor in the hypertension of experimental coarctation of the aorta. Surgery. 1951;30:206-17.

4. Eisenman B. In memoriam: Henry T. Bahnson. Baltimore: CTSNet; 2003. Available from: http://www.ctsnet.org/doc/7368. Accessed September 1, 2012.

5. Stoney WS. Henry T. Bahnson, MD. In: Pioneers of cardiac surgery. Vanderbilt University Press; 2008:187.

6. Bahnson HT. Considerations in the excision of aortic aneurysms. Ann Surg. 1953; 138:377-86.

7. Bahnson HT, Otis AB. Physiological considerations of cardiovascular surgery Physiol Rev. 1955;35:363-80.

8. Bahnson HT, Spencer FC, Landtman B, Wolf MD, Neill CA, Taussig HB. Surgical treatment and follow-up of 147 cases of tetralogy of Fallot treated by correction. J Thorac Cardiovasc Surg. 1962;44:419-32.

9. Bahnson HT, Spencer FC, Busse EF, Davis FW. Cusp replacement and coronary artery perfusion in open operations on the aortic valve. Ann Surg. 1960;152:494-505.

10. Bahnson HT. Closed chest cardiac resuscitation. Surg Gynecol Obstet. 1961;112: 622-3.

11. McGinley L. Of artificial hearts and artificial harps in a Pittsburgh lab: cardiac surgeon and bioengineer study a harmonica virtuoso from inside his mouth. The Wall Street Journal. February 28, 1999:A1, A10.

12. The fantastic voyage harmonica style. Pittsburgh: AntakaMatics; 2009. Available from: http://www.youtube.com/watch?v=gTEXSb6duVs. Accessed September $1,2012$.

13. Bahnson HT, Antaki JF, Beery QC. Acoustical and physical dynamics of the diatonic harmonica. J Acoust Soc Am. 1998;103:2134-44.

14. Hardesty RL, Griffith BP, Mathews RA, Siewers RD, Neches WH, Park SC, et al Discrete subvalvular aortic stenosis. An evaluation of operative therapy. J Thorac Cardiovasc Surg. 1977;74:352-61.

15. Bahnson HT. Our obligation to developing nations. J Thorac Cardiovasc Surg. 1977; 74:168-73

16. In memoriam: Henry T. Bahnson, MD. Ann Surg. 2003;237:591-2. 